\title{
Progeria, a model for accelerated aging exhibited by HIV patients?
}

Pierre Cau

From $16^{\text {th }}$ International Symposium on HIV and Emerging Infectious Diseases

Marseille, France. 24-26 March 2010

\begin{abstract}
Aim
To confirm, among HIV1-infected patients, data from in vitro studies showing that antiretroviral therapies (ART) induce an accelerated aging through the same mechanism than genetic laminopathies (progeria) and « physiological " aging, i.e. through the synthesis and persistence of farnesylated prelamin A. The perspective is to minimize ART side effects using the same drug combination yet given to treat progeria children in Marseille.
\end{abstract}

\section{Materials and methods}

A multicentric (Marseille, Nice and Montpellier Hospitals) 3 year-long study will analyse 50 HIV1-infected patients without any ART (A group), 100 infected patients receiving ART for at least 12 months (B group) and 50 age- and sex-matched seronegative control subjects. Infected patients will be submitted to 4 successive investigations (M0, M12, M24 and M36).

Biological tests are performed in Timone Hospital labs (Marseille): i/ viral load, PBMC isolation, DNA extraction, proviral DNA measurement [Virology]; ii/ CD4, CD8, glycemia, insulinemia, HOMA, total-, LDL- and HDL-cholesterol, triglycerides [Biochemistry labs from the 3 Hospitals]; iii/ ART assay [Pharmacokinetics Lab]; iv/ detection (western blot, immunocytochemistry) of PBMC nuclear, cytosolic and mitochondrial ART targets: A and B lamins, NF-kB and I-kB (proteasome activity), CD36 (glycosylation), mitochondrial Hsp70, ROS production, inner membrane potential, cytochrome C oxidase subunits 2 and 4 [Cell Biology]; v/ genotyping the ART targets: prelamin A and B processing proteases, Golgi SREBP-releasing proteases, mitochondrial deoxynucleoside transporters and proteases involved in

INSERM UMR_S 910, Faculté de Médecine, 27 Bd Jean Moulin and Laboratoire de Biologie Cellulaire, Hôpital de La Timone, 264 Rue Saint Pierre, 13385 Marseille Cedex 5, France nuclear-encoded protein import; telomere length [Molecular Genetics]. CIC-UPCET collaborated to the protocol design, recruits control subjects and is in charge of data statistical treatment.

\section{Results and discussion}

The M0 collection just finished. Mitochondrial data will be presented.

Acknowledgements

Granted by ANRS (EP45 « Aging " study) and SIDACTION.

Published: 11 May 2010

doi:10.1186/1742-4690-7-S1-129

Cite this article as: Cau: Progeria, a model for accelerated aging exhibited by HIV patients?. Retrovirology 2010 7(Suppl 1):I29.

Submit your next manuscript to BioMed Central and take full advantage of:

- Convenient online submission

- Thorough peer review

- No space constraints or color figure charges

- Immediate publication on acceptance

- Inclusion in PubMed, CAS, Scopus and Google Scholar

- Research which is freely available for redistribution

Submit your manuscript at www.biomedcentral.com/submit 